\title{
Sucrose Esters from Physalis peruviana Calyces with Anti-Inflammatory Activity
}

Authors

Affiliations
Luis A. Franco ${ }^{1}$, Yanet C. Ocampo ${ }^{1}$, Harold A. Gómez ${ }^{1}$, Rocío De la Puerta ${ }^{2}$, José L. Espartero ${ }^{3}$, Luis F. Ospina ${ }^{4}$

${ }^{1}$ Biological Evaluation of Promissory Substances Group, Faculty of Pharmaceutical Sciences, University of Cartagena, Cartagena, Colombia

2 Pharmacology Department, Faculty of Pharmacy, University of Seville, Seville, Spain

${ }^{3}$ Organic Chemistry Department, Faculty of Pharmacy, University of Seville, Seville, Spain

${ }^{4}$ Pharmacy Department, Faculty of Sciences, National University of Colombia, Bogotá, Colombia
Key words

- sucrose esters

- Physalis peruviana

- Solanaceae

- NO

- PGE2

- TNF- $\alpha$

- antiinflammatory activity $\begin{array}{ll}\text { received } & \text { May 15, } 2014 \\ \text { revised } & \text { July 12, } 2014 \\ \text { accepted } & \text { Sept. 18, } 2014\end{array}$

Bibliography

DOI http://dx.doi.org/

10.1055/s-0034-1383192

Published online October 22,

2014

Planta Med 2014; 80:

1605-1614 ㄷ Georg Thieme

Verlag KG Stuttgart - New York

ISSN 0032-0943

\section{Correspondence}

Prof. Dr. Luis A. Franco

Biological Evaluation of

Promissory Substances Group

Faculty of Pharmaceutical

Sciences

University of Cartagena

Consulado Ave. Street 30

No. 48-152

130015 Cartagena

Colombia

Phone: + 5756699771

Fax: + 5756698323

Ifrancoo@unicartagena.edu.co

\section{Abstract}

$\nabla$

Physalis peruviana is a native plant from the South American Andes and is widely used in traditional Colombian medicine of as an anti-inflammatory medicinal plant, specifically the leaves, calyces, and small stems in poultice form. Previous studies performed by our group on $P$. peruviana calyces showed potent anti-inflammatory activity in an enriched fraction obtained from an ether total extract. The objective of the present study was to obtain and elucidate the active compounds from this fraction and evaluate their anti-inflammatory activity in vivo and in vitro. The enriched fraction of $P$. peruviana was purified by several chromatographic methods to obtain an inseparable mixture of two new sucrose esters named peruviose A (1) and peruviose B (2). Structures of the new compounds were elucidated using spectroscopic methods and chemical transformations. The anti-inflammatory activity of the peruvioses mixture was evaluated using $\lambda$-carrageenan-induced paw edema in rats and lipopolysaccharide-activated peritoneal macrophages. Results showed that the peruvioses did not produce side effects on the liver and kidneys and significantly attenuated the inflammation induced by $\lambda$-carrageenan in a dosage-dependent manner, probably due to an inhibition of nitric oxide and prostaglandin E2, which was demon-

\section{Introduction}

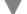

Inflammation is a frequent and immediate response to external and internal injurious stimuli including infections, chemicals, physical stress, and immune pathologies. It is a complex phenomenon that involves many cell types and cellular pathways [1]. Molecules produced during inflammation trigger pain receptors, induce local vasodilatation, and recruit phagocytic cells, espe- strated in vitro. To our knowledge, this is the first report of the presence of sucrose esters in $P$. peruviana that showed a potent anti-inflammatory effect. These results suggest the potential of sucrose esters from the Physalis genus as a novel natural alternative to treat inflammatory diseases.

\section{Abbreviations \\ $\nabla$ \\ COX-2: $\quad$ cyclooxygenase 2 \\ IL: interleukin \\ iNOS: $\quad$ inducible nitric oxide synthase \\ LPS: lipopolysaccharide \\ m.a.s.l.: meters above sea level \\ MTT: 3-(4,5-dimethylthiazol-2-yl)-2,5- diphenyltetrazolium bromide \\ NO•: $\quad$ nitric oxide \\ PGE2: $\quad$ prostaglandin E2 \\ RPMI: Roswell Park Memorial Institute \\ SNP: $\quad$ sodium nitroprusside \\ TNF- $\alpha$ : $\quad$ tumor necrosis factor alpha \\ TPA: 12-0-tetradecanoyl-phorbol-13- acetate}

$1400 \mathrm{~W}: \quad \mathrm{N}-[[3-($ aminomethyl)phenyl]methyl]ethanimidamide dihydrochloride

Supporting information available online at http://www.thieme-connect.de/products

cially neutrophils and macrophages, which then activate other immune system components [2]. Excessive or persistent inflammation leads to the overproduction of mediators that are a key factor for the development of severe pathologies such as rheumatoid arthritis [3], bacterial sepsis [4], asthma [5], atherosclerosis [6], inflammatory bowel disease [7], and cancer [8], which represents an important cause of morbidity worldwide. Thus, the reduction or elimination of the persistent in- 
flammatory response and/or the overproduction of proinflammatory mediators is an important target to prevent or treat these diseases [9].

Plants represent an excellent source to obtain new drugs, as they constitute an immense reservoir of structurally diverse secondary metabolites that might potentially inhibit the inflammatory process by affecting different molecular targets [4]. In this sense, Physalis peruviana L. (Solanaceae), widely used in traditional medicine as a diuretic and hypoglycemic agent and to treat malaria, asthma, hepatitis, dermatitis, and rheumatoid arthritis [10], represents a promissory source of bioactive compounds. This has been experimentally validated, with extracts showing relevant antioxidant [11,12], antiproliferative [13-15], cytotoxic [16], anti-hepatotoxic [17], hipoglycaemic [18], immunomodulatory [19], and anti-inflammatory activities [20,21].

$P$. peruviana, also known as "uchuva" in Colombia or "gooseberry" in English speaking countries, is native to tropical South America and is characterized because the fruit grows enclosed in a papery husk or calyx, which is one of the best-known examples of persistent sepals due to its conspicuous post-floral growth and enlargement [22-24]. The $P$. peruviana calyx protects the fruit against insects, birds, diseases, and adverse climatic situations; this structure represents an essential source of carbohydrates during the first 20 days of growth and development of the fruit, and the conservation of it even after harvest, allowing for a shelf life of one month, whereas without the calyx, it is only lasts for 4 to 5 days or so $[23,24]$. Three varieties of $P$. peruviana are currently grown, originating from Colombia, Kenya, and South Africa. The ecotype Colombia, which has a great demand on the international markets, presents small and colorful fruits and different morphological characteristics in the calyx [25]. Although the fruit is highly appreciated for its commercial value, the calyx constitutes a waste generated in fruit production as well as an unexplored source of bioactive molecules.

The experimental studies of $P$. peruviana have been focused on the chemical and biological characterization of the whole plant, stems, leaves, and fruits, with only a few reports for calyces. Chemical studies on $P$. peruviana, mainly of the aerial parts, showed the presence of withanolides, steroids, alkaloids, and glycosides [15-17,23,26]. Phytochemical studies made by our research group on $P$. peruviana calyces indicated the presence of flavonoids, steroids and/or triterpenes, and lactones $\alpha-\beta$ unsaturated. Our previous studies also demonstrated that the major fraction obtained from the ether extract of $P$. peruviana calyces showed potent anti-inflammatory activity in a TPA-induced ear edema model, with inhibition to nearly $70 \%$ [20]. In this work, we elucidated the structure of two new sucrose esters from this major fraction and evaluated their anti-inflammatory activity in vivo in the $\lambda$-carrageenan-induced paw edema model and the in vitro effect on NO•, PGE2, and TNF- $\alpha$ production from LPS-stimulated murine macrophages. Sucrose esters have been isolated from Physalis species in fruits, flowers, and stems [27-29]. To our knowledge, this is the first report on the presence of sucrose esters in calyces of the Physalis genus.

\section{Results and Discussion}

$\nabla$

Colum chromatographic purification of the methanol-water soluble fraction, obtained by liquid/liquid partition from the total ether extract of $P$. peruviana calyces, provided a major fraction which constituted $3.03 \%$ of the initial material and was subjected to preparative TLC to lead to the isolation of one spot that showed a single peak on reversed-phase HPLC. However, spectroscopic signals of this fraction revealed a mixture of two new sucrose esters, peruvioses A ( 1 ) and B (2), occurring in a 6:4 ratio, respectively. All attempts at the separation of the components with several combinations of solvent systems using preparative TLC and HPLC were ineffective. Therefore, we elucidated their structures by analyzing the spectroscopic data of the mixture.

Compounds $\mathbf{1}$ and $\mathbf{2}$ were isolated as a gummy solid, with a 99.05\% purity based on HPLC that exhibited strong absorption bands for hydroxyl $\left(v=3411 \mathrm{~cm}^{-1}\right)$ and saturated ester functions $\left(v=1746 \mathrm{~cm}^{-1}\right)$ in the IR spectrum. Despite the fact that it was a mixture, NMR spectra displayed many duplicated peaks slightly displaced and MS showed similar but distinguishable fragmentation pathways, which allowed for the elucidation of both compounds separately.

${ }^{1} \mathrm{H}-\mathrm{NMR}$ and ${ }^{13} \mathrm{C}$-NMR signals and the connectivities observed in the HMBC and NOESY spectra for 1 revealed the presence of one pyranose and one furanose unit as the monomers of a disaccharide structure, as well as four acyl substituents: one decanoyl and three isobutanoyl chains ( Table 1 and Fig. 1 ). The relative configuration of the sugars was determined by comparing the ${ }^{1} \mathrm{H}-\mathrm{NMR}$ coupling constants and ${ }^{13} \mathrm{C}-\mathrm{NMR}$ chemical shifts with literature values [26-29]. The pyranose was identified as $\alpha$-Dglucopyranose by the observed coupling constants $\left(J_{1,2}=3.7 \mathrm{~Hz}\right.$, $J_{2,3}=10.4 \mathrm{~Hz}, J_{3,4}=J_{4,5}=9.4 \mathrm{~Hz}$ ) that also established $\mathrm{H}-1$ as equatorial, whereas the strong coupling observed between $\mathrm{H}-2$ and $\mathrm{H}$ $3, \mathrm{H}-3$ and $\mathrm{H}-4$, and $\mathrm{H}-4$ and $\mathrm{H}-5$ established these protons as axial. On the other hand, the furanose was identified as $\beta$-D-fructofuranose showing the following coupling constants: $J_{3^{\prime}} 4^{\prime}\left(H 3^{\prime}\right)=$ $J_{3^{\prime}} 4^{\prime}\left(\mathrm{H} 4^{\prime}\right)=8.2 \mathrm{~Hz}$. The NOE contact between glucose $\mathrm{H}-1$ to $\mathrm{H}-1 \mathrm{a}^{\prime}$ and $\mathrm{H}-1 \mathrm{~b}^{\prime}$ of the fructose ring confirmed the glycosidic linkage with $\alpha$ - and $\beta$-orientations on the anomeric carbon for D-glucose and $D$-fructose, respectively. Moreover, the HMBC signal between H-1 and C-2' unequivocally indicates the 1,2 linkage between Dglucose and D-fructose (Fig. 1S, Supporting Information).

The positions of all substituents in the disaccharide structure were determined from the analysis of the HMBC spectrum, which showed correlations between $\mathrm{H}-2$ and the carboxylic carbon $\mathrm{C}$ 1 ". This data evidences that the aliphatic decanoyl chain is placed in position 2 of the glucose unit. On the other hand, the HMBC spectrum showed correlations between $\mathrm{H}-3$ of the glucopyranose and C-1"' of an isobutanoyl group, which, in turn, was coupled with $\mathrm{H}-3^{\prime \prime \prime}$. The same bidimensional spectrum showed connectivities of $\mathrm{H}-4$ with $\mathrm{C}-1^{\prime \prime \prime}$ of another isobutanoyl group, which was coupled with $\mathrm{H}-3^{\prime \prime \prime \prime}$. In the furanose moiety, a clear correlation between $\mathrm{H}-3^{\prime}$ and carboxylic C-1"'"' was found, indicating that another isobutanoyl substituent was located in position 3 of this unit.

This analysis led us to elucidate the structure of the new compound as 2-O-decanoyl-3,3',4-tri-O-isobutanoylsucrose, named peruviose $A$ (1), $\mathrm{C}_{34} \mathrm{H}_{58} \mathrm{O}_{15}$. The adduct ion peak at $m / z 729[\mathrm{M}+$ $\mathrm{Na}]^{+}$obtained by FABMS, as well as fragments at $m / z 155$ (decanoyl) and $m / z 71$ (isobutanoyl), are in agreement with the proposed molecular formula and structure. Additionally, the ion peak at $m / z 897[\mathrm{M}+\mathrm{Na}]^{+}$(calcd. for $\mathrm{C}_{42} \mathrm{H}_{66} \mathrm{O}_{19} \mathrm{Na}$ ) of the corresponding acetylated derivate confirmed the presence of the four ester groups, while the fragment at $m / z 233$ supported the proposed substitution of the furanose moiety.

Compound 2 was identified on the basis of 1D and 2D NMR analyses and FABMS spectra in a similar manner. These analyses pointed out that both compounds shared an almost identical 
Table 1 NMR spectroscopic data for peruviose $\mathrm{A}(\mathbf{1})$ in $\mathrm{CDCl}_{3}\left(500 \mathrm{MHz}\right.$ for ${ }^{1} \mathrm{H}$ and $125 \mathrm{MHz}$ for $\left.{ }^{13} \mathrm{C}\right)$.

\begin{tabular}{|c|c|c|c|c|}
\hline Number & ${ }^{1} \mathrm{H}\left[\delta(\mathrm{ppm}), m,{ }^{3} J(\mathrm{~Hz})\right]$ & ${ }^{13} \mathrm{C}(\delta, \mathrm{ppm}) / \mathrm{DEPT}$ & NOESY & НMBC \\
\hline Glucose-1 & $5.59, d, 3.7$ & $89.40 / \mathrm{CH}$ & $\mathrm{H}-2, \mathrm{H}-1^{\prime} \mathrm{a}, \mathrm{H}-1^{\prime} \mathrm{b}$ & $C-5, C-2^{\prime}$ \\
\hline 2 & $4.96-4.90^{*}$ & $70.06 / \mathrm{CH}$ & $\mathrm{H}-1^{\prime} \mathrm{a}$ & $C-3, C-1^{\prime \prime}$ \\
\hline 3 & $5.48, \mathrm{dd}, 10.4,9.4$ & $69.02 / \mathrm{CH}$ & $\mathrm{H}-5$ & C-2, C-4, C-1'"' \\
\hline 4 & $4.96-4.90^{*}$ & $68.25 / \mathrm{CH}$ & $\mathrm{H}-6$ & $C-3, C-5, C-6, C-1^{\prime \prime \prime \prime}$ \\
\hline 5 & $4.19-4.12^{*}$ & $72.18 / \mathrm{CH}$ & $\mathrm{H}-6$ & \\
\hline 6 & $3.60, m$ & $61.60 / \mathrm{CH}_{2}$ & $\mathrm{H}-4^{\prime}$ & \\
\hline Fructose-1'a & $3.58, d, 12.0$ & $64.69 / \mathrm{CH}_{2}$ & $\mathrm{H}-3^{\prime}, \mathrm{H}-5^{\prime}$ & \\
\hline $1 ' b$ & $3.45, d, 12.0$ & & $\mathrm{H}-3^{\prime}$ & \\
\hline $2^{\prime}$ & - & $103.81 / \mathrm{C}$ & & \\
\hline $3^{\prime}$ & $5.20, d, 8.2$ & $79.26 / \mathrm{CH}$ & $H-5^{\prime}$ & $C-1^{\prime}, C-4^{\prime}, C-1^{\prime \prime \prime \prime \prime}$ \\
\hline $4^{\prime}$ & $4.56, t, 8.2$ & $71.19 / \mathrm{CH}$ & $H-6^{\prime} a, H-6^{\prime} b$ & $C-3^{\prime}, C-5^{\prime}, C-6^{\prime}$ \\
\hline $5^{\prime}$ & $3.94, m$ & $82.55 / \mathrm{CH}$ & & $\mathrm{C}-4^{\prime}$ \\
\hline 6'a & $3.90, m$ & $59.73 / \mathrm{CH}_{2}$ & & $C-4^{\prime}$ \\
\hline $6^{\prime} b$ & $3.74, m$ & & & \\
\hline $1^{\prime \prime}$ & - & $172,88 / C=0$ & & \\
\hline $2^{\prime \prime}$ & $2.25, m$ & $33.85 / \mathrm{CH}_{2}$ & $\mathrm{H}-3^{\prime \prime}, \mathrm{H}-4^{\prime \prime}$ & $\mathrm{C}-3^{\prime \prime}$ \\
\hline $3^{\prime \prime}$ & $1.54, m$ & $24.55 / \mathrm{CH}_{2}$ & $\mathrm{H}-4^{\prime \prime}$ & $C-2^{\prime \prime}$ \\
\hline $4^{\prime \prime}-7^{\prime \prime}$ & 1.24, s wide & $29.33-29.06 / \mathrm{CH}_{2}$ & & \\
\hline $8^{\prime \prime}$ & $1.24, s$ wide & $31.82 / \mathrm{CH}_{2}$ & & \\
\hline $9^{\prime \prime}$ & 1.24, s wide & $22.63 / \mathrm{CH}_{2}$ & & \\
\hline $10^{\prime \prime}$ & $0.87, t, 7.0$ & $14.06 / \mathrm{CH}_{3}$ & & $C-8^{\prime \prime}, C-9^{\prime \prime}$ \\
\hline $1^{\prime \prime \prime}$ & - & $175.74 / C=O$ & & \\
\hline $2^{\prime \prime \prime}$ & $2.45, m, 7.0$ & $33.89 / \mathrm{CH}$ & $\mathrm{H}-3^{\prime \prime \prime} \mathrm{a}, \mathrm{H}-3^{\prime \prime \prime \prime} \mathrm{b}$ & \\
\hline 3"'a & $1.07, d, 7.0$ & $18.79-18.70 / \mathrm{CH}_{3}$ & & $\mathrm{C}-2^{\prime \prime \prime}$ \\
\hline $3^{\prime \prime \prime} b$ & $1.08, d, 7.0$ & & & $C-2^{\prime \prime \prime}$ \\
\hline $1^{\prime \prime \prime \prime}$ & - & $175.98 / C=0$ & & \\
\hline $2^{\prime \prime \prime \prime}$ & $2.51, m, 7.0$ & $33.93 / \mathrm{CH}$ & $\mathrm{H}-3^{\prime \prime \prime \prime \prime} \mathrm{a}, \mathrm{H}-3^{\prime \prime \prime \prime \prime b}$ & $\mathrm{C}-3^{\prime \prime \prime \prime}$ \\
\hline $3^{\prime \prime \prime \prime}$ & $1.13, d, 7.0$ & $18.79-18.70 / \mathrm{CH}_{3}$ & & C-2'"', \\
\hline $3^{\prime \prime \prime \prime \prime b}$ & $1.06, d, 7.0$ & & & $\mathrm{C}-2^{\prime \prime \prime \prime}$ \\
\hline $1^{\prime \prime \prime \prime \prime}$ & - & $177.87 / C=0$ & & \\
\hline $2^{\prime \prime \prime \prime \prime}$ & $2.75, m, 7.0$ & $34.02 / \mathrm{CH}$ & H-3"','”a, H-3'"','b & $\mathrm{C}-3^{\prime \prime \prime \prime \prime \prime}$ \\
\hline $3^{\prime \prime \prime \prime \prime \prime a ~}$ & $1.32, d, 7.0$ & $18.87 / \mathrm{CH}_{3}$ & & $C-2^{\prime \prime \prime \prime \prime}$ \\
\hline $3^{\prime \prime \prime \prime \prime b}$ & $1.29, d, 7.0$ & $18.87 / \mathrm{CH}_{3}$ & & $C-2^{\prime \prime \prime \prime \prime}$ \\
\hline
\end{tabular}

* The multiplicity could not be determined

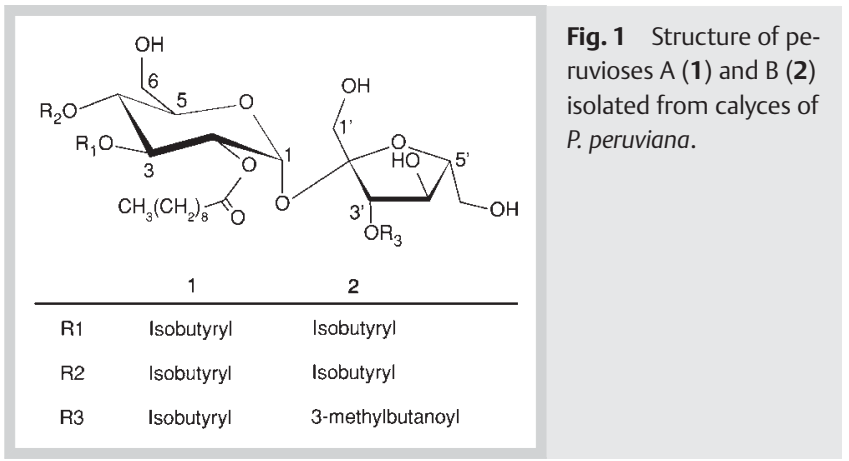

structure with an esterified sucrose core with four acyl groups ( $\triangle$ Table 2 and Fig. $\mathbf{1}$ ). The only difference between these compounds was observed in the HMBC correlations of 2 with the presence of a connectivity signal between $\mathrm{H}-3^{\prime}$ and C- $1^{\prime \prime \prime \prime}$, corresponding to a 3-methylbutanoyl substituent. The quasimolecular ion peak $\mathrm{m} / \mathrm{z} 743[\mathrm{M}+\mathrm{Na}]^{+}$obtained by FABMS, as well as fragments at $m / z 155$ (decanoyl), $m / z 71$ (isobutanoyl), and $m / z 85$ (3-methylbutanoyl), supported the structural characteristics of the acyl groups. The peak at $m / z 247$ also corroborates the difference on the furanose moiety substitution and confirms the structure of the new sucrose ester derivative as 2-O-decanoyl-3,4-di$O$-isobutyryl-3'-O-(3-methylbutanoyl)sucrose, named peruviose
B, $\mathrm{C}_{35} \mathrm{H}_{60} \mathrm{O}_{15}$. After acetylation of this compound, the ion peak at $\mathrm{m} / z 911[\mathrm{M}+\mathrm{Na}]^{+}$(calcd. for $\mathrm{C}_{43} \mathrm{H}_{68} \mathrm{O}_{19} \mathrm{Na}$ ) also confirmed the presence of the four original ester groups on the sugar moiety.

Determination of the absolute configuration of the sugar moiety was performed by alkaline hydrolysis and comparison with a sucrose authentic standard. The hydrolysis of peruvioses A and B ( 1 and 2) with $\mathrm{NH}_{4} \mathrm{OH}(2 \mathrm{M}$ ) yielded a product with an identical absolute configuration $\left([\alpha]_{\mathrm{D}}^{20^{\circ} \mathrm{C}}\right.$ product $\left.=+62.2\right)$ in respect to the sucrose standard $\left([\alpha]_{\mathrm{D}}^{20^{\circ} \mathrm{C}}\right.$ standard $\left.=+66\right)$.

Acylsucroses are considered the main protective constituents of the resin covering the inner parts of the calyces of several Physalis species, since other known sucrose esters exhibit aphicidal, molluscidal, and antifeedant activities [29]. Consequently, we performed an acute toxicity evaluation of the mixture of peruviose A and B, which did not produce mortality or visible signs of toxicity within $24 \mathrm{~h}$ when administered intraperitoneally (i.p.) at doses below $100 \mathrm{mg} / \mathrm{kg}$. Doses higher than $200 \mathrm{mg} / \mathrm{kg}$ produced a toxic effect in a dose-dependent manner with slight hypoactivity, weakness, and labored breathing before animal death, accompanied by permanent piloerection ( $\left(\right.$ Table 3 ). The $\mathrm{LD}_{50}$ was estimated to be 223.59 (95\% confidence interval 209.91-234.52) $\mathrm{mg} / \mathrm{kg}$.

The toxicity of peruvioses A and B was significantly high as expected, not only because of the known toxicity of sugar esters [30], but also because of the nearly complete access of the tested compounds to the general circulation. However, subchronic and 
Table 2 NMR spectroscopic data for peruviose $\mathrm{B}(2)$ in $\mathrm{CDCl}_{3}\left(500 \mathrm{MHz}\right.$ for ${ }^{1} \mathrm{H}$ and $125 \mathrm{MHz}$ for ${ }^{13} \mathrm{C}$ ).

\begin{tabular}{|c|c|c|c|c|}
\hline Number & ${ }^{1} \mathrm{H}\left[\delta(\mathrm{ppm}), \mathrm{m},{ }^{3} J(\mathrm{~Hz})\right]$ & ${ }^{13} \mathrm{C}(\delta, \mathrm{ppm}) / \mathrm{DEPT}$ & NOESY & HMBC \\
\hline Glucose-1 & $5.60, d, 3.8$ & $89.42 / \mathrm{CH}$ & $\mathrm{H}-2, \mathrm{H}-1^{\prime} \mathrm{a}, \mathrm{H}-1^{\prime} \mathrm{b}$ & $C-5, C-2^{\prime}$ \\
\hline 2 & $4.96-4.90^{*}$ & $70.13 / \mathrm{CH}$ & $\mathrm{H}-1$ 'a & $\mathrm{C}-3, \mathrm{C}-1^{\prime \prime}$ \\
\hline 3 & $5.46, \mathrm{dd}, 10.3,9.4$ & $69.05 / \mathrm{CH}$ & $\mathrm{H}-5$ & $C-2, C-4, C-1^{\prime \prime \prime}$ \\
\hline 4 & $4.96-4.90^{*}$ & $68.30 / \mathrm{CH}$ & $\mathrm{H}-6$ & $C-3, C-5, C-6, C-1^{\prime \prime \prime \prime}$ \\
\hline 5 & $4.19-4.12^{*}$ & $72.01 / \mathrm{CH}$ & $\mathrm{H}-6$ & \\
\hline 6 & $3.60, m$ & $61.55 / \mathrm{CH}_{2}$ & $\mathrm{H}-4^{\prime}$ & \\
\hline Fructose-1'a & $3.58, d, 12.0$ & $64.54 / \mathrm{CH}_{2}$ & $\mathrm{H}-3^{\prime}, \mathrm{H}-5^{\prime}$ & \\
\hline $1 ' b$ & $3.45, d, 12.0$ & & $\mathrm{H}-3^{\prime}$ & \\
\hline $2^{\prime}$ & - & $103.89 / C$ & & \\
\hline $3^{\prime}$ & $5.23, d, 8.2$ & $79.12 / \mathrm{CH}$ & $H-5^{\prime}$ & $\mathrm{C}-1^{\prime}, \mathrm{C}-4^{\prime}, \mathrm{C}-1^{\prime \prime \prime \prime \prime}$ \\
\hline $4^{\prime}$ & $4.56, t, 8.2$ & $71.15 / \mathrm{CH}$ & $H-6^{\prime} a, H-6^{\prime} b$ & $C-3^{\prime}, C-5^{\prime}, C-6^{\prime}$ \\
\hline $5^{\prime}$ & $3.96, m$ & $82.55 / \mathrm{CH}$ & & $C-4^{\prime}$ \\
\hline 6'a & $3.92, m$ & $59.79 / \mathrm{CH}_{2}$ & & $C-4^{\prime}$ \\
\hline $6^{\prime} b$ & $3.71, m$ & & & \\
\hline $1^{\prime \prime}$ & - & $172,88 / \mathrm{C}=\mathrm{O}$ & & \\
\hline $2^{\prime \prime}$ & $2.25, m$ & $33.85 / \mathrm{CH}_{2}$ & $\mathrm{H}-3^{\prime \prime}, \mathrm{H}-4^{\prime \prime}$ & $C-3^{\prime \prime}$ \\
\hline $3^{\prime \prime}$ & $1.54, m$ & $24.55 / \mathrm{CH}_{2}$ & $\mathrm{H}-4^{\prime \prime}$ & $C-2^{\prime \prime}$ \\
\hline $4^{\prime \prime}-7^{\prime \prime}$ & 1.24 , s wide & $29.33-29.06 / \mathrm{CH}_{2}$ & & \\
\hline $8^{\prime \prime}$ & 1.24 , s wide & $31.82 / \mathrm{CH}_{2}$ & & \\
\hline $9^{\prime \prime}$ & 1.24, s wide & $22.63 / \mathrm{CH}_{2}$ & & \\
\hline $10^{\prime \prime}$ & $0.87, t, 7.0$ & $14.06 / \mathrm{CH}_{3}$ & & $C-8^{\prime \prime}, C-9^{\prime \prime}$ \\
\hline $1^{\prime \prime \prime}$ & - & $175.64 / C=0$ & & \\
\hline $2^{\prime \prime \prime}$ & $2.45, m, 7.0$ & $33.88 / \mathrm{CH}$ & $\mathrm{H}-3$ "'’a, H-3"'”b & \\
\hline 3"'a & $1.08, d, 7.0$ & $18.79-18.70 / \mathrm{CH}_{3}$ & & $C-2^{\prime \prime \prime}$ \\
\hline $3{ }^{\prime \prime \prime} b$ & $1.07, d, 7.0$ & & & $C-2^{\prime \prime \prime}$ \\
\hline $1^{\prime \prime \prime \prime}$ & - & $176.06 / C=0$ & & \\
\hline $2^{\prime \prime \prime \prime}$ & $2.52, m, 7.0$ & $33.91 / \mathrm{CH}$ & $H-3^{\prime \prime \prime \prime}$ a, $\mathrm{H}-3^{\prime \prime \prime \prime \prime b}$ & $\mathrm{C}-3^{\prime \prime \prime \prime}$ \\
\hline 3"'”a & $1.144, d, 7.0$ & $18.79-18.70 / \mathrm{CH}_{3}$ & & $C-2^{\prime \prime \prime \prime}$ \\
\hline $3^{\prime \prime \prime \prime b}$ & $1.119, d, 7.0$ & & & $C-2^{\prime \prime \prime \prime}$ \\
\hline $1^{\prime \prime \prime \prime \prime}$ & - & $174.06 / C=0$ & & \\
\hline $2^{\prime \prime \prime \prime \prime}$ & 2.39, ABX-system, 7.0, 14.8 & $43.14 / \mathrm{CH}_{2}$ & $\mathrm{H}-4^{\prime \prime \prime \prime \prime \prime a, ~} \mathrm{H}-4^{\prime \prime \prime \prime \prime \prime b ~}$ & C-4"','”a \\
\hline $3^{\prime \prime \prime \prime \prime}$ & $2.20, m$ & $25.86 / \mathrm{CH}$ & $\mathrm{H}-4^{\prime \prime \prime \prime \prime \prime a, ~} \mathrm{H}-4^{\prime \prime \prime \prime \prime b}$ & $C-2^{\prime \prime \prime \prime \prime}$ \\
\hline 4 "'”'’a & $1.05, d, 6.7$ & $22.42 / \mathrm{CH}_{3}$ & & $\mathrm{C}-2^{\prime \prime \prime \prime \prime}, \mathrm{C}-3^{\prime \prime \prime \prime \prime}, \mathrm{C} 4^{\prime \prime \prime \prime \prime} \mathrm{b}$ \\
\hline 4 "'”'b & $1.04, d, 6.7$ & $22.29 / \mathrm{CH}_{3}$ & & $\mathrm{C}-2^{\prime \prime \prime \prime \prime}, \mathrm{C}-3^{\prime \prime \prime \prime \prime}, \mathrm{C}-4^{\prime \prime \prime \prime \prime} \mathrm{a}$ \\
\hline
\end{tabular}

* The multiplicity could not be determined

Table 3 Acute toxicity in mice after $24 \mathrm{~h}$ administration of a mixture of peruvioses $\mathrm{A}$ and $\mathrm{B}$ isolated from $P$. peruviana calyces.

\begin{tabular}{|c|c|c|c|}
\hline Dose $(\mathrm{mg} / \mathrm{Kg})^{\mathrm{a}}$ & $\mathrm{D} / \mathrm{T}^{\mathrm{b}}$ & Mortality latencyc & Signs of toxicity observed \\
\hline 0 & $0 / 6$ & - & No toxic changes observed. \\
\hline 100 & $0 / 6$ & - & No toxic changes observed. Abdominal contractions. ${ }^{d}$ \\
\hline 150 & $0 / 6$ & - & \multirow[t]{2}{*}{ Abdominal contractions. Slight hypoactivity in the first $30 \mathrm{~min}$. } \\
\hline 175 & $0 / 6$ & - & \\
\hline 200 & $0 / 6$ & - & Abdominal contractions. Slight hypoactivity in the first $2 \mathrm{~h}$. \\
\hline 215 & $3 / 6$ & $>5 \mathrm{~h},<24 \mathrm{~h}$ & $\begin{array}{l}\text { Abdominal contractions. Piloerection. Slight hypoactivity in the first } 2 \mathrm{~h} \text {. } \\
\text { Marked hypoactivity, peripheral cyanosis, and respiratory arrest before death. }\end{array}$ \\
\hline 230 & $4 / 6$ & $>5 \mathrm{~h},<24 \mathrm{~h}$ & \multirow{4}{*}{$\begin{array}{l}\text { Abdominal contractions. Piloerection. Marked hypoactivity. Peripheral cya- } \\
\text { nosis and respiratory arrest before death. }\end{array}$} \\
\hline 240 & $5 / 6$ & $>3 \mathrm{~h},<24 \mathrm{~h}$ & \\
\hline 250 & $5 / 6$ & $>5 \mathrm{~h},<24 \mathrm{~h}$ & \\
\hline 300 & $6 / 6$ & $3-10 \mathrm{~h}$ & \\
\hline
\end{tabular}

a The mixture of peruvioses A and B was co-precipitated with PVP K-25, dissolved in saline, and administered as a single i.p. dose to groups of six mice, which were carefully examined for any signs of behavioral changes and mortality for $24 \mathrm{~h}$; ${ }^{\mathrm{b}} \mathrm{D} / \mathrm{T}$ refers to the number of mice deaths/total number of mice; ${ }^{\mathrm{c}}$ Mortality latency refers to the time to death (in hours) after the injection; ${ }^{\mathrm{d}}$ Abdominal contractions were noted only after the administration of treatments (10-20 min)

chronic toxicological evaluations, employing several routes of administration, are needed before conducting further studies with these molecules.

During necropsy, a macroscopic examination did not show detectable changes in the shape, color, or size of the liver and kid- neys due to the administration of peruvioses $A$ and $B$. In addition, a histopathological evaluation did not reveal significant changes in tissue architecture, inflammatory cell infiltration, swelling, or necrosis in comparison to the control group ( $\odot$ Fig. 2 ). Our results directly demonstrated that toxicity induced by peruvioses $\mathrm{A}$ and 


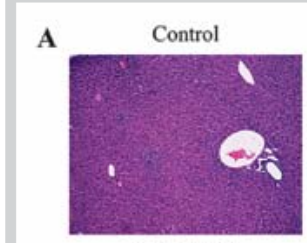

$200 \mathrm{mg} / \mathrm{Kg}$

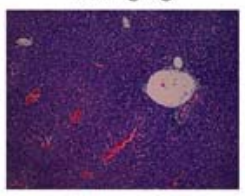

$215 \mathrm{mg} / \mathrm{Kg}$
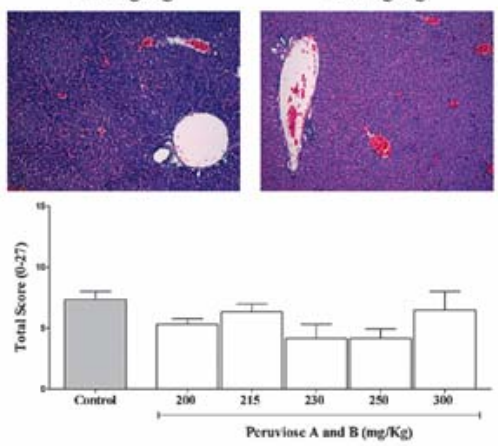

B

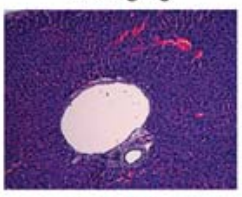

$250 \mathrm{mg} / \mathrm{Kg}$

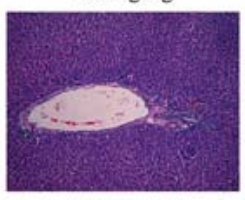

$300 \mathrm{mg} / \mathrm{Kg}$

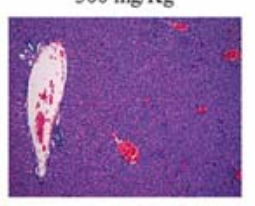

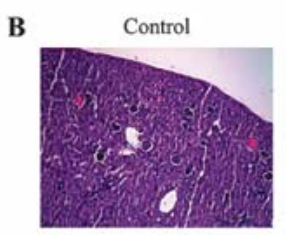

$200 \mathrm{mg} / \mathrm{Kg}$

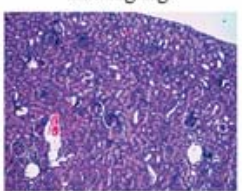

$215 \mathrm{mg} / \mathrm{Kg}$
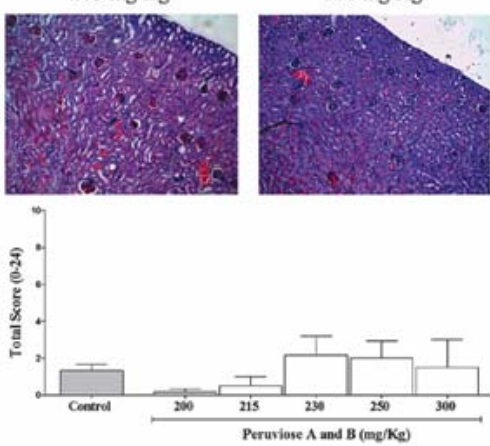

Fig. 2 Peruvioses $A$ and $B$ isolated from $P$. peruviana calyces did not produce an effect on the histological structure of the liver (A) and kidneys (B) of mice treated i.p. with doses of the mixture of sucrose esters ranging from 0 (control) to $300 \mathrm{mg} / \mathrm{kg}$ for $24 \mathrm{~h}$. Micrographs are representative of a histological section of organs stained with hematoxylin and eosin from at least six different animals. Magnification $10 \times$. Scores were assigned by a blinded pathologist according to the parameters established in Table 1S, Supporting Information. Each value represents the mean \pm SEM. (Color figure available online only.)
$B$ is not mediated through effects on liver or kidney function. Future studies should include examination of other vital organs like the brain, heart, lungs, and spleen.

Based on the experimental $\mathrm{LD}_{50}$, we decided to select doses lower than $200 \mathrm{mg} / \mathrm{kg}$ to evaluate the anti-inflammatory effect of sucrose esters employing the $\lambda$-carrageenan paw edema test, a classical model of acute inflammation for the discovery of antiedematous agents [31]. Subplantar injection of $\lambda$-carrageenan generated an increase in paw volume of the rats in the control group, which intensified progressively to reach a maximum peak at $5 \mathrm{~h}$ (134.15\% increase). As can be seen in 0 Fig. 3, the peruviose A and $B$ mixture $(25,50$, and $100 \mathrm{mg} / \mathrm{Kg}$, i.p. $)$ significantly inhibited the edema induced by $\lambda$-carrageenan in a dose-dependent manner as early as $1 \mathrm{~h}$ after induction of inflammation. The highest effect of the mixture was produced at $3 \mathrm{~h}$ by the dose of $100 \mathrm{mg} / \mathrm{kg}$ (62.58 $\pm 3.35 \%$ inhibition).

In vivo anti-inflammatory activity of four related sucrose esters isolated from Physalis sordida $\left(\mathrm{Cl}_{50}=0.24-0.35 \mu \mathrm{mol} / \mathrm{ear}\right)$ has been recently described [32]. We have also demonstrated the effect of the major glycosidic fraction from $P$. peruviana calyces, which includes peruvioses $A$ and $B$ among its constituents, using the TPA-induced ear edema model [20]. These experimental evidences suggest that the presence of sucrose esters can be highly related to the anti-inflammatory activity exerted by some plants of this genus [32]. However, the mechanism underlying this pharmacological activity has not been described.

Edema is an essential feature of acute inflammation caused by increased vascular permeability $[33,34]$. The effect induced by $\lambda$ carrageenan is a biphasic response with multiple mediators acting in sequence. The first phase $(0-1 \mathrm{~h})$ is triggered through the rapid release of histamine, serotonin, and bradykinin. The more pronounced second phase (1-6h) is elicited by the production of prostaglandins and $\mathrm{NO}$ by inducible isoforms of COX-2 and iNOS, respectively $[33,35]$. Since our results suggest that the anti-inflammatory effect produced by the mixture of peruvioses
$A$ and $B$ is due to the inhibition of the synthesis or release of the proinflammatory mediators from the second phase, and considering a previous study which reported inhibition of LPS-induced NO• and PGE2 generation on RAW 264.7 macrophages by a supercritical fluid extract of $P$. peruviana leaves [21], we decided to further evaluate the effect of the mixture of sucrose esters from $P$. peruviana calyces in the production of some of the major mediators of acute inflammation, NO•, PGE2, and TNF- $\alpha$, by LPSstimulated mouse peritoneal macrophages.

Macrophages play a pivotal role in host defense against bacterial infection, being the principal cellular target for LPS, the major component in the outer membrane of gram-negative bacteria cell walls, which stimulates the secretion of NO and PGE2 as well as proinflammatory cytokines including TNF- $\alpha$, IL- $1 \beta$, and IL-6 [36]. To verify whether peruvioses $A$ and $B$ are able to inhibit the production of NO and PGE2, we first evaluated their effect on cell viability by employing the MTT assay. As shown in Fig. $4 \mathrm{~A}$, the mixture of peruvioses inhibited the cell viability in a concentration-dependent manner, with an $\mathrm{LC}_{50}$ value of 25.41 (15.2840.24) $\mu \mathrm{g} / \mathrm{mL}$, without exerting significant toxicity at $10 \mu \mathrm{g} / \mathrm{mL}$. Therefore, concentrations employed in the subsequent experiments were equal or less than this concentration.

$\mathrm{NO} \cdot$ is a gaseous signaling molecule that plays a crucial role in host defense mechanisms via its antimicrobial and cytoprotective activities. Stimulation of murine macrophages by LPS results in the increased expression of iNOS, which catalyzes the production of large amounts of NO• We found that peritoneal macrophages produced a considerable amount of nitrite under basal conditions, $21.82 \pm 1.25 \mu \mathrm{M}$. However, after stimulation with LPS, nitrite production was increased significantly to a concentration of $65.44 \pm 3.42 \mu \mathrm{M}$. Nontoxic concentrations of the mixture of peruvioses $A$ and $B$ produced a significant reduction of nitrite production depending on the concentration, IC $_{50}=2.317$ (1.3684.055) $\mu \mathrm{g} / \mathrm{mL}$, showing a similar activity for that presented by $1400 \mathrm{~W}$ ( Fig. 4B), without exerting an important scavenging ef- 


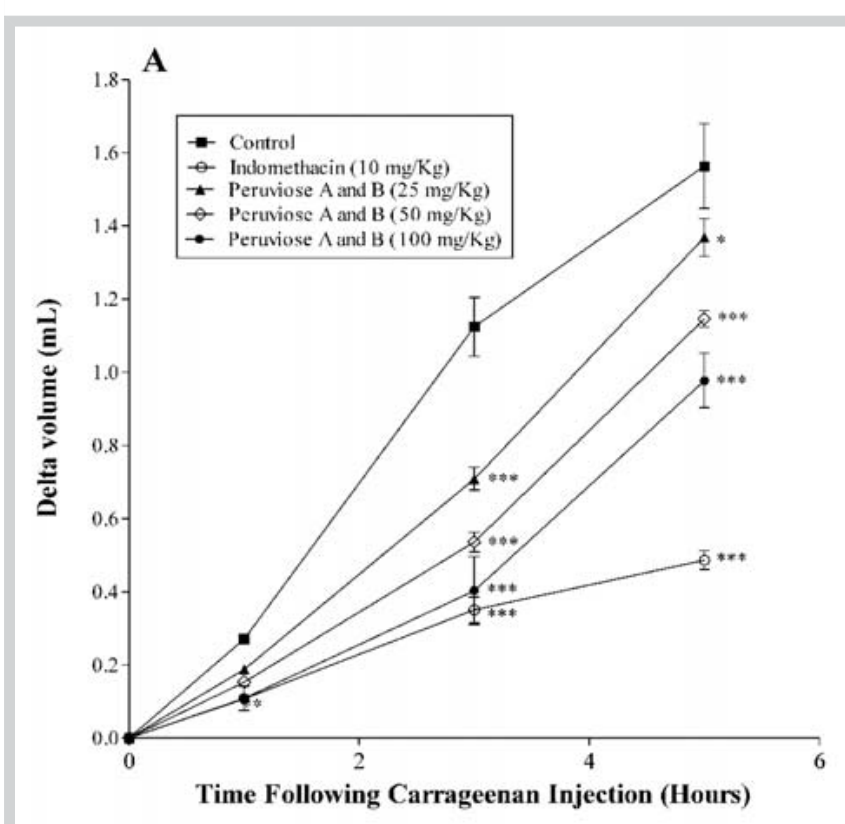

Fig. 3 Anti-inflammatory effect of the mixture of peruvioses $A$ and $B$ on $\lambda$ carrageenan-induced paw edema. Six rats per group were administered sucrose esters $(25,50$, and $100 \mathrm{mg} / \mathrm{kg}$, i. p.) or indomethacin ( $10 \mathrm{mg} / \mathrm{kg}$, i. p.), $1 \mathrm{~h}$ before the $\lambda$-carrageenan injection. Paw volume was measured at 1,3 , and $5 \mathrm{~h}$ intervals, after phlogistic agent administration, and data expressed as

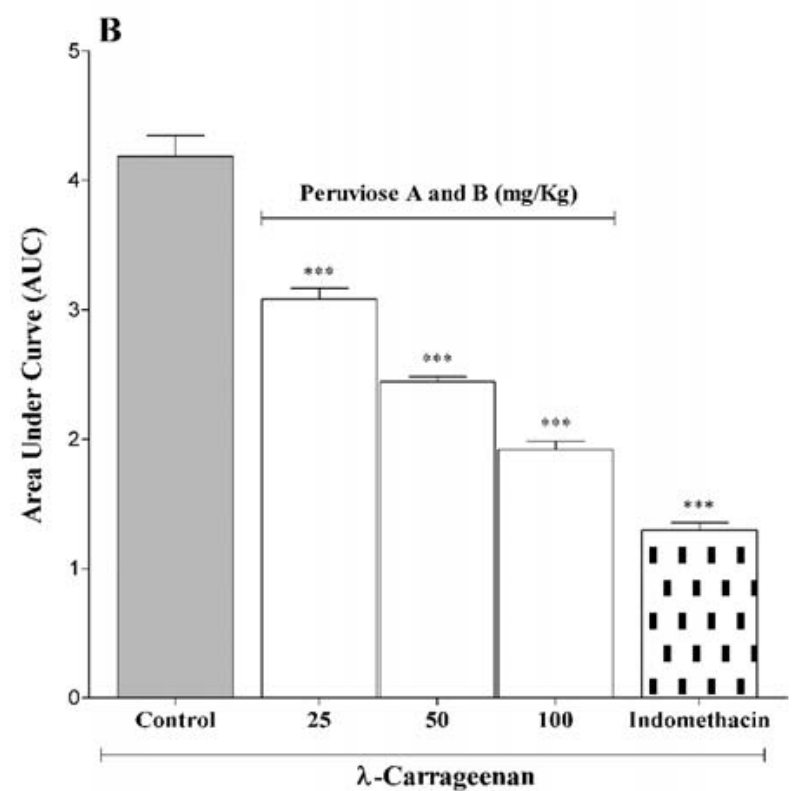

fect of NO• (Table 4S, Supporting Information), indicating that suppression of its release can be directly attributed to a blocked production by stimulated macrophages.

PGE2 is known to be a key mediator of immunopathology in chronic inflammatory diseases and cancer [37]. As can be seen in O Fig. 4C, LPS produced a significant increase of PGE2 levels in cell culture, changing its concentration from $4.18 \pm 0.38 \mathrm{ng} / \mathrm{mL}$ to $27.43 \pm 0.61 \mathrm{ng} / \mathrm{mL}$. The mixture of peruvioses A and B exhibited a potent inhibitory effect on PGE2 release in cell culture in a concentration-dependent manner, with $\mathrm{IC}_{50}=0.072$ (0.019$0.293) \mu \mathrm{g} / \mathrm{mL}$. The effects of the mixture of sucrose esters are comparable to those of rofecoxib, which is a selective COX-2 inhibitor.

In vitro anti-inflammatory activity through the inhibition of PGE2 production of LPS-induced RAW 264.7 macrophages by three sucrose esters isolated from Bidens parviflora has also been described [38]. Taken together, these results suggest that the anti-inflammatory activity of sucrose esters might be related to the inhibition of this important prostanoid.

TNF- $\alpha$ is a potent proinflammatory cytokine released primarily from stimulated macrophages playing a critical role in the host response to infection and injury [39]. LPS-stimulated macrophages significantly increased TNF- $\alpha$ production in 2.93 -fold (O Fig. 4D). Unexpectedly, the mixture of peruvioses A and B did not affect the production of TNF- $\alpha$, even at the highest tested concentration, which suggests that the anti-inflammatory activity of these sucrose esters is mediated through the selective downregulation of iNOS and COX-2, independently of common pathways or transcription factors with TNF- $\alpha$.

Of the mediators that modulate PGE2 synthesis in macrophages, NO• seems to play a key role. A large body of evidence suggests that there is significant crosstalk between iNOS and COX-2 biosynthetic pathways, especially in biological systems like LPS-

(A) delta volume $(\mathrm{mL})$, which denotes the degree of swelling after $\lambda$-carrageenan treatment or (B) area under curve (arbitrary units). Each value represents the mean \pm SEM. ${ }^{*} \mathrm{P}<0.05,{ }^{* *} \mathrm{P}<0.01,{ }^{* * *} \mathrm{P}<0.001$, ANOVA followed by the Dunnett test, statistically significant compared with the control group. stimulated peritoneal macrophages [40]. However, the final effect of these interactions is often unclear, varying between different kinds of cells and tissues [41,42]. Further studies are needed to clarify the effect of peruvioses A and B on iNOS and COX-2 in peritoneal macrophages.

In conclusion, we described the isolation of a mixture of two new anti-inflammatory sucrose esters from the calyces of $P$. peruviana. Overall, our results suggest that sucrose esters are important anti-inflammatory compounds of the Physalis genus, mainly through the downregulation of NO• and PGE2 production, without exerting significant acute toxicity.

\section{Material and Methods \\ $\nabla$}

\section{Experimental instrumentation and chemicals}

Melting points were determined by differential scanning calorimetry-DSC7 (Perkin-Elmer) and are uncorrected. IR spectrum was recorded on a FTIR (Perkin Elmer 1600 series). NMR spectra were obtained on a Bruker AMX-500 spectrometer, with TMS as the internal standard. FAB-MS was obtained on a Kratos MS80RFA mass spectrometer. A Hitachi-LaChrom Elite ${ }^{\circledR}$ apparatus equipped with PDA was used for analytical HPLC separations. Reversed-phase chromatography was performed with a $100 \times$ $4.6 \mathrm{~mm}$ Chromolith ${ }^{\circledR}$ C-18 column (Merck). TLC was performed on silica gel 60 F254 plates ( $250 \mu$ m thickness; Merck). Silica gel $60(0.063-0.200 \mathrm{~mm})$ and $\mathrm{NH}_{4} \mathrm{OH}$ were also obtained from Merck. All solvents were of analytical grade and purchased from Merck. A plethysmometer (model 7140 Ugo Basile) was used to determine the paw volume in rats. To work with cell cultures, thioglycollate broth, RPMI-1640 medium, FBS, PBS tablets, antibiotics, $\mathrm{N}$-(1-naphthyl)-ethylenediamine, sulfanilamide, $\lambda$-carrageenan, LPS, $1400 \mathrm{~W}$ (purity $>98 \%$ ), $\mathrm{NaNO}_{2}$, SNP, indomethacin 


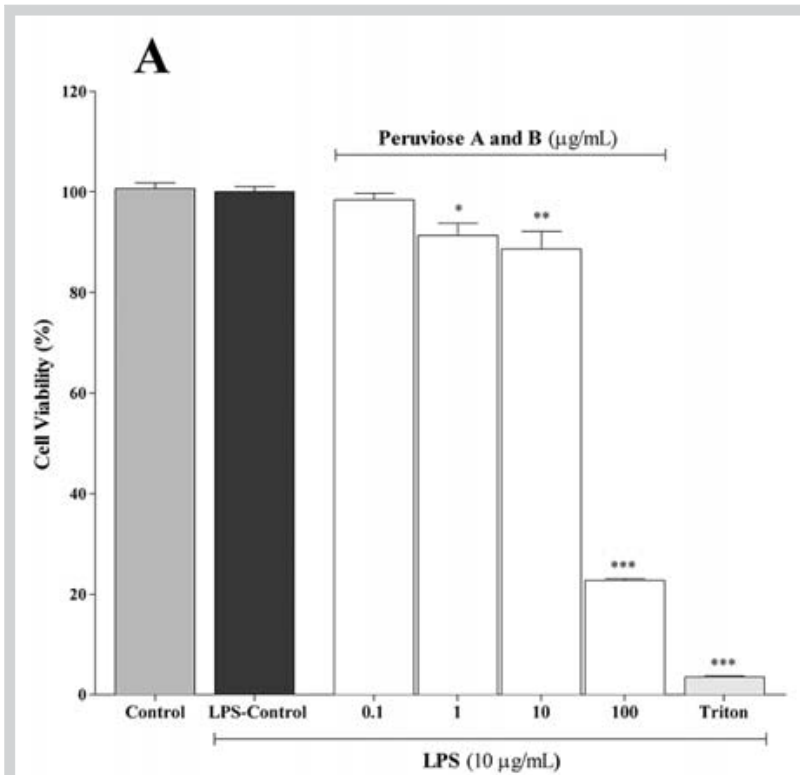

C

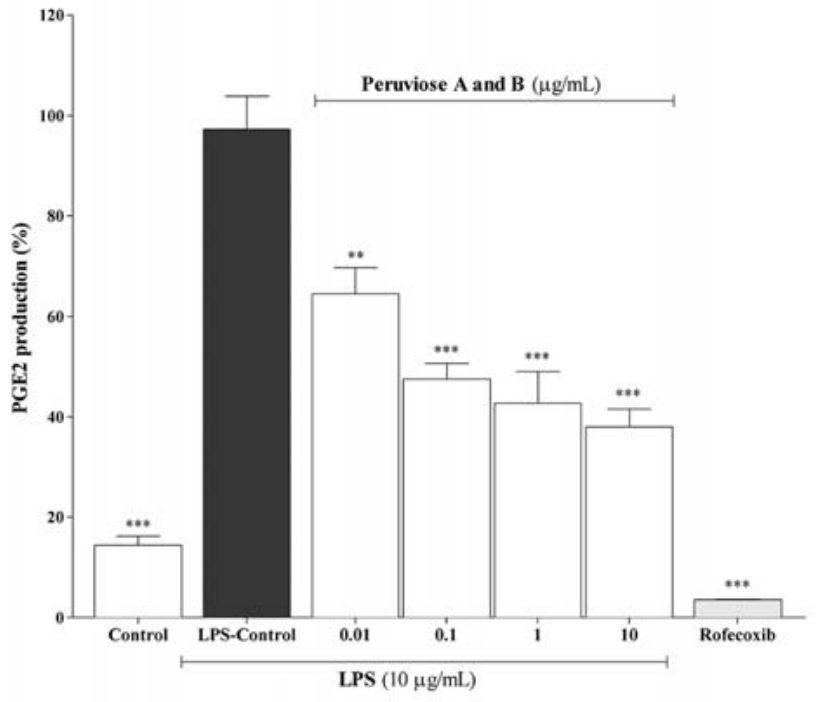

Fig. 4 Effect of the mixture of peruvioses $A$ and $B$ on lipopolysaccharide-induced mouse peritoneal macrophages viability and proinflammatory mediator production. Macrophages were treated with various concentrations of the mixture of sucrose esters $(0.01-100 \mu \mathrm{g} / \mathrm{mL})$ for $30 \mathrm{~min}$, and activated with LPS $(10 \mu \mathrm{g} / \mathrm{mL})$ for $24 \mathrm{~h}$. After incubation, cell viability was determined by the MTT assay (A) or culture supernatants were collected. Nitrite production was

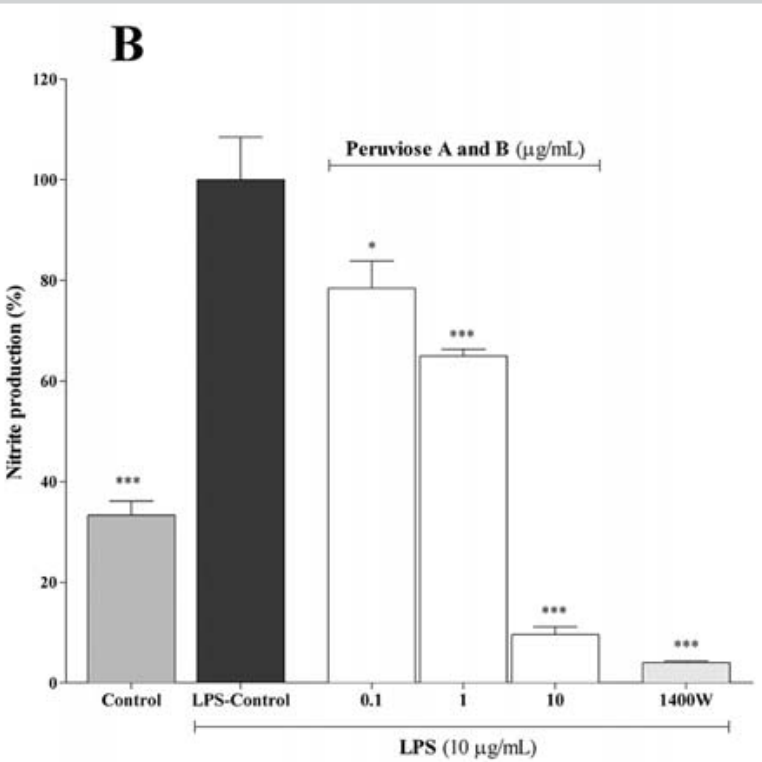

D

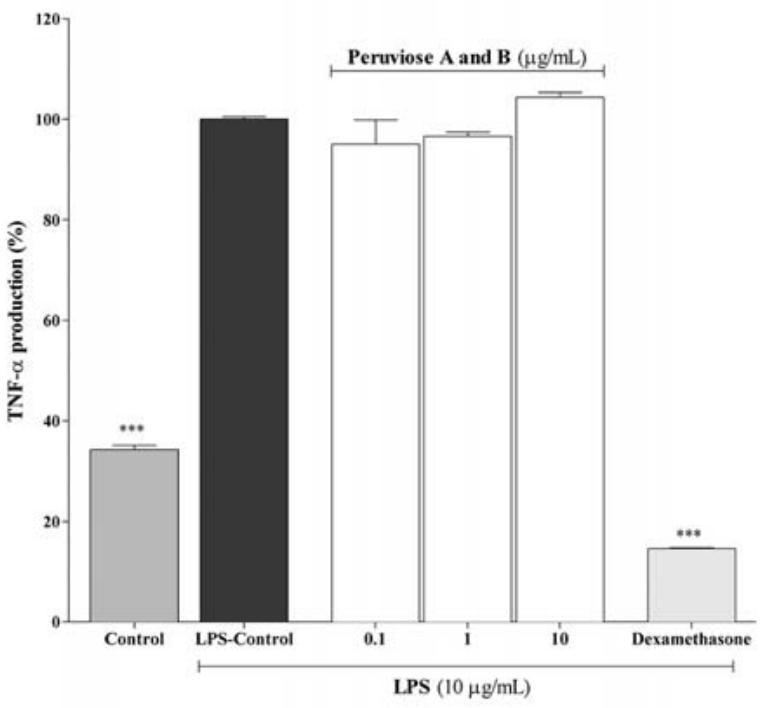

assessed using Griess reaction (B), and ELISA was employed to quantify PGE2 (C) and TNF- $\alpha$ release (D). Triton X-100 ${ }^{\circledR}(20 \%), 1400 \mathrm{~W}(2.50 \mu \mathrm{g} / \mathrm{mL})$, rofecoxib $(6.29 \mu \mathrm{g} / \mathrm{mL})$, and dexamethasone $(7.85 \mu \mathrm{g} / \mathrm{mL})$ were employed as positive controls, respectively. Results are expressed as the mean \pm SME of at least two independent experiments. ${ }^{*} \mathrm{P}<0.05,{ }^{* *} \mathrm{P}<0.01,{ }^{* * *} \mathrm{P}<0.001$, ANOVA followed by the Dunnett test, compared with the LPS-treated group. (purity 98-101\%), dexamethasone (purity $\geq 97 \%$ ), curcumin (purity $\geq 80 \%$ ), and DMSO were obtained from Sigma-Aldrich. MTT, rofecoxib (purity $>99 \%$ ), and caffeic acid (purity $\geq 95 \%$ ) were purchased from Calbiochem ${ }^{\circledR}$.

\section{Plant material}

Calyces of $P$. peruviana L. were collected in La Mesa, Colombia (43' 49.22" N; 74²7' 45.60" W; elevation 1198 m.a.s. I.) in November 2003. Taxonomic identification was performed by Clara I. Orozco at Herbario Nacional Colombiano (Instituto de Ciencias Naturales, Universidad Nacional de Colombia), Bogotá, Colombia, where a voucher specimen (COL-512200) has been deposited.

\section{Extraction and isolation}

Dried calyces $(2 \mathrm{~kg}$ ) were powdered and extracted with petroleum ether by percolation at room temperature until exhaustion of the material. The concentrated extract $(271.6 \mathrm{~g}$ ) was partitioned with ether and methanol-water $(9: 1)$ to give a polar fraction (223.3 g). This fraction ( $22 \mathrm{~g}$ ) was subjected to column chromatography (CC, $14 \times 30 \mathrm{~cm}$ columns) on silica gel (600 g, $0.063-$ $0.200 \mathrm{~mm}$ ) and eluted with petroleum ether, dichloromethane, ethyl acetate, and methanol mixtures, gradually increasing the polarity. Fractions were combined based on TLC examination using a proper mobile phase and visualized by heating after spraying with Godin reagent [43] to obtain 38 main fractions with a 
94.77\% efficiency. The major fraction (8.23 g), named Pp- $\mathrm{D}_{28}-\mathrm{LF}$ [20], was subjected to analytical HPLC analysis using a mixture of methanol and $0.07 \mathrm{M}$ monobasic potassium phosphate buffer (6.5:3.5, pH 4.0) as the mobile phase, a $1 \mathrm{~mL} / \mathrm{min}$ flow rate, and an operating temperature of $25^{\circ} \mathrm{C}$ to show one component that constituted nearly $82 \%$ of the mixture. This major fraction $(2 \mathrm{~g})$ was purified by $\mathrm{CC}$ (gradient elution $\mathrm{CH}_{2} \mathrm{Cl}_{2}$ to EtOAc) followed by two successive preparative TLCs (eluent $\mathrm{CH}_{2} \mathrm{Cl}_{2}$-EtOAc $4: 6$ ) to yield $293 \mathrm{mg}$ of an inseparable mixture of two new sucrose esters, peruviose A (1) and peruviose B (2). Their structures were elucidated trough IR, FAB-MS, and extensive 2D NMR methods including ${ }^{1} \mathrm{H}-\mathrm{NMR},{ }^{13} \mathrm{C}-\mathrm{NMR}$, Dep90, Dep135, HMBC, and NOESY. Peruvioses $A$ and $B$ (1 and 2): Light yellow gummy solid mixture of 1 and 2; Rf 0.489 on silica gel $60 \mathrm{~F}-254\left(\mathrm{CH}_{2} \mathrm{Cl}_{2} / \mathrm{EtOAc}, 4: 6\right)$; purity (HPLC) 99.05\% [ $t_{\mathrm{R}} 2.35 \mathrm{~min} ; \mathrm{CH}_{3} \mathrm{OH} / \mathrm{KH}_{2} \mathrm{PO}_{3}(0.07 \mathrm{M})$, 6.5:3.5, pH 4.0]; m.p. $20-22^{\circ} \mathrm{C}$ (uncorrected); UV (EtOH) $\lambda_{\max }$ $220 \mathrm{~nm} ;[\alpha]_{\mathrm{D}}^{20^{\circ} \mathrm{C}}=+52.08, \mathrm{IR}(\mathrm{KBr}) v_{\max } 3411,2927,2858,1746$, 1191, 1155, 1063, $1017 \mathrm{~cm}^{-1}$; ${ }^{1} \mathrm{H}-\mathrm{NMR}$ (500 MHz, $\left.\mathrm{CDCl}_{3}\right)$, ${ }^{13} \mathrm{C}-\mathrm{NMR}, \mathrm{HMBC}$, and NOESY $\left(125 \mathrm{MHz}, \mathrm{CDCl}_{3}\right.$ ) spectra, see $\bullet \mathrm{Ta}-$ ble 1 and Fig. $2 S$ and 3S, Supporting Information. FAB-MS: (1) $\mathrm{m} / \mathrm{z}$ $729[\mathrm{M}+\mathrm{Na}]^{+}$(calcd. for $\mathrm{C}_{34} \mathrm{H}_{58} \mathrm{O}_{15} \mathrm{Na}$ ), $\mathrm{m} / z 233\left[\mathrm{C}_{10} \mathrm{H}_{17} \mathrm{O}_{6}\right], \mathrm{m} / z$ $155\left[\mathrm{C}_{10} \mathrm{H}_{19} \mathrm{O}\right]$, and $\mathrm{m} / z 71\left[\mathrm{C}_{4} \mathrm{H}_{7} \mathrm{O}\right] ;$ ( (2) $\mathrm{m} / z 743[\mathrm{M}+\mathrm{Na}]^{+}$, (calcd. for $\left.\mathrm{C}_{35} \mathrm{H}_{60} \mathrm{O}_{15} \mathrm{Na}\right), m / z 247\left[\mathrm{C}_{11} \mathrm{H}_{19} \mathrm{O}_{6}\right], m / z 155\left[\mathrm{C}_{10} \mathrm{H}_{19} \mathrm{O}\right], m / z 85$ $\left[\mathrm{C}_{5} \mathrm{H}_{9} \mathrm{O}\right]$, and $m / z 71\left[\mathrm{C}_{4} \mathrm{H}_{7} \mathrm{O}\right]$, Fig. 4S, Supporting Information.

\section{Chemical modifications}

To verify the presence of glycosylated esters and the absolute configuration of the sugar moiety, the mixture of peruvioses $\mathrm{A}$ and $\mathrm{B}(10 \mathrm{mg})$ was hydrolyzed with $2 \mathrm{~mL}$ of $\mathrm{NH}_{4} \mathrm{OH} 2 \mathrm{M}$ for $4 \mathrm{~h}$ at $50^{\circ} \mathrm{C}$. The reaction mixture was adjusted to $\mathrm{pH} 3$ by the addition of formic acid $2 \mathrm{M}$ and subjected to successive liquid-liquid extraction with ethyl acetate $(3 \times 3 \mathrm{~mL})$. The aqueous solution was used to determine the absolute configuration of glycosides. Additionally, $90 \mathrm{mg}$ of the compound mixture were acetylated by the usual procedure with acetic anhydride and pyridine $(5: 1$ per gram of the compound) to yield $90.9 \mathrm{mg}$ of the acetylated material (efficiency $81.9 \%$ ), after the usual workup. Acetylated peruvioses $\mathrm{A}$ and $\mathrm{B}$ ( $\mathbf{3}$ and $\mathbf{4}$ ) were submitted to ${ }^{1} \mathrm{H}-\mathrm{NMR},{ }^{13} \mathrm{C}-\mathrm{NMR}$, Dep90, Dep135, HMBC, NOESY, and FABMS to confirm the elucidation of their structure.

Acetylated peruvioses $A$ and $B$ (3 and 4): Light yellow gummy solid; NMR ( $500 \mathrm{MHz}, \mathrm{CDCl}_{3}$ ) data are described in Table $\mathbf{2 S}$ and 35, Supporting Information. FAB-MS: $m / z 897[\mathrm{M}+\mathrm{Na}]^{+}$(calcd. for $\mathrm{C}_{42} \mathrm{H}_{66} \mathrm{O}_{19} \mathrm{Na}$ ) and $\mathrm{m} / z 911[\mathrm{M}+\mathrm{Na}]^{+}$(calcd. for $\mathrm{C}_{43} \mathrm{H}_{68} \mathrm{O}_{19} \mathrm{Na}$ ).

\section{Experimental animals}

Female Wistar rats (140-170 g) and ICR mice (20-25 g) were provided by Instituto Nacional de Salud, Colombia. Animals were allowed to acclimatize for ten days before use and fed with standard rodent food and water ad libitum. They were housed in filtered-capped polycarbonate cages and kept in a controlled environment at $22 \pm 3{ }^{\circ} \mathrm{C}$ and relative humidity between 65 to $75 \%$, under a cycle of $12 \mathrm{~h}$ light/darkness. Animals were sacrificed by cervical dislocation at the corresponding time of each experiment. All experiments were designed and conducted in accordance with the guidelines of the Ethics Committee of the University of Cartagena (minutes of October 23, 2010) and the European Union regulations (CEC council 86/809).

\section{Acute toxicity}

The acute toxicity test was carried out to evaluate any possible toxic effect exerted by the mixture of peruvioses A and B from $P$. peruviana calyces. Mice were randomly divided into ten groups of six animals per group and treated intraperitoneally with graded doses of sucrose esters ranging from 0 (control) to $300 \mathrm{mg} / \mathrm{kg}$. Mice were observed for $24 \mathrm{~h}$ post-treatment for mortality, behavioral changes, and signs of toxicity. The $\mathrm{LD}_{50}$ value was determined by the Miller and Tainter method [44]. At the end of experiment, all animals were sacrificed, and the kidneys and liver were carefully excised for histological examination, fixed in $4 \%$ buffered formaldehyde, embedded in paraffin, and stained with hematoxylin and eosin using standard techniques. All slides were coded and evaluated in a blinded manner by a pathologist observer according to the parameters described in Table 1S, Supporting Information.

\section{$\lambda$-Carrageenan paw edema}

The anti-inflammatory activity was evaluated according to the method described by Winter et al. [45]. Edema was induced by subplantar injection of $\lambda$-carrageenan ( $0.1 \mathrm{~mL}$ of a $2 \%$ solution) in the right hind paw of each animal. Rats were randomly divided into three groups of six animals each, and saline (control), indomethacin $10 \mathrm{mg} / \mathrm{kg}$ (positive control), or the mixture of peruvioses $A$ and $B(100,50$, and $25 \mathrm{mg} / \mathrm{kg})$ was prophylactically administered (i.p.) $1 \mathrm{~h}$ before the administration of $\lambda$-carrageenan. Paw volume was determined by means of a volume displacement method using a plethysmometer immediately prior to the injection of $\lambda$-carrageenan and 1,3 , and 5 h thereafter. Edema was expressed as the increase in paw volume $(\mathrm{mL})$ after $\lambda$-carrageenan injection relative to the preinjection value for each animal.

\section{Isolation and culture of peritoneal macrophages}

Peritoneal macrophages were isolated from ICR mice three days after i.p. injection of $10 \%$ sterile thioglycollate broth $(1 \mathrm{~mL})$. Peritoneal exudate cells were obtained by lavage with $20 \mathrm{~mL}$ of cold sterile PBS, pH 7.4, supplemented with $2 \%$ antibiotics (penicillin $100 \mathrm{U} / \mathrm{mL}$ and streptomycin $100 \mu \mathrm{g} / \mathrm{mL}$ ). The cells were placed in RPMI-1640 medium with $2 \%$ antibiotics and $10 \%$ FBS, seeded in 24-well plates $\left(1 \times 10^{6}\right.$ cells $\left./ \mathrm{mL}\right)$, and incubated at $37^{\circ} \mathrm{C}$ in a $5 \%$ $\mathrm{CO}_{2}$ atmosphere. The isolation and purification of the macrophages were carried out by adherence to culture plates. After a period of $2 \mathrm{~h}$, non-adherent cells were washed off with PBS. The adherent cells were treated for $30 \mathrm{~min}$ with various concentrations of the peruviose A and B mixture $(0.01-10 \mu \mathrm{g} / \mathrm{mL}), 1400 \mathrm{~W}$ $(2.50 \mu \mathrm{g} / \mathrm{mL})$, dexamethasone $(7.85 \mu \mathrm{g} / \mathrm{mL})$, and rofecoxib $(6.29 \mu \mathrm{g} / \mathrm{mL})$, stimulated with LPS $(10 \mu \mathrm{g} / \mathrm{mL})$, and incubated for $24 \mathrm{~h}$. Culture supernatants were collected and assayed for NO•, PGE2, and TNF- $\alpha$ levels as described below. Control cells were cultured under the same conditions but were not activated.

\section{MTT assay}

The mitochondrial-dependent reduction of MTT to formazan was used to assess the cytotoxic effect of the test compounds [46,47]. Cells $\left(1 \times 10^{6}\right.$ cells $\left./ \mathrm{mL}\right)$ were cultured at $37^{\circ} \mathrm{C}$ with various concentrations of peruvioses A and B $(0.1-100 \mu \mathrm{g} / \mathrm{mL})$. Triton X-100 $(20 \%)$ was used as a positive control. After $24 \mathrm{~h}$, the medium was removed and cells were incubated with MTT solution $(3 \mathrm{mg} / \mathrm{mL})$. Four hours later, the medium was carefully aspirated and formazan crystals were dissolved in DMSO $(100 \mu \mathrm{L})$. The $\mathrm{OD}_{550}$ was measured using a microplate reader (Multiscan EX Thermo ${ }^{\circledR}$ ). 


\section{$\mathrm{NO} \cdot$ production}

NO release was determined spectrophotometrically by the accumulation of $\mathrm{NO}_{2}{ }^{-}$, a stable metabolite of the reaction of $\mathrm{NO} \cdot$ with oxygen, using the Griess reaction [48]. Briefly, $100 \mu$ l of cell culture supernatant were mixed with $100 \mu \mathrm{L}$ of Griess reagent [1:1 mixture of $0.1 \% \mathrm{~N}$-(1-naphthyl) ethylenediamine dihydrochloride and $1 \%$ sulfanilamide in $5 \% \mathrm{H}_{3} \mathrm{PO}_{4}$ ], and incubated at room temperature for $5 \mathrm{~min}$. The $\mathrm{OD}_{550}$ of the samples was measured using a microplate reader (Multiscan EX Thermo ${ }^{\circledR}$ ) and compared with a standard curve prepared with $\mathrm{NaNO}_{2}(1-200 \mu \mathrm{M})$.

Additionally, a direct NO scavenging effect of peruvioses A and B was determined as described in Supporting Information.

\section{Tumor necrosis factor- $\alpha$ and prostaglandin E2 release}

Levels of TNF- $\alpha$ and PGE2 in culture supernatants were determined using commercially available competitive ELISA kits (R\&D Systems) according to the manufacturer's instructions. The final results are expressed as $\mathrm{ng} / \mathrm{mL}$.

\section{Statistical analysis}

Data are presented as mean \pm SEM. Concentrations that inhibited cell survival $\left(\mathrm{LC}_{50}\right)$ and inflammatory mediators $\left(\mathrm{IC}_{50}\right)$ by $50 \%$ were calculated employing nonlinear regression. Statistical comparisons between groups were established using analysis of variance (ANOVA), followed by Dunnett test post hoc analysis. P values less than 0.05 were considered statistically significant.

\section{Supporting information}

Methods to determine the NO--scavenging effect of peruvioses A (1) and B (2), as well as the scoring criteria of liver and kidney sections for histological analysis are described in Supporting Information. Results of the radical scavenging effect, in addition to FABMS and NMR spectra for $\mathbf{1}$ and $\mathbf{2}$, and NMR spectra for the acetylated compounds ( $\mathbf{3}$ and $\mathbf{4}$ ) are also included.

\section{Acknowledgements \\ $\nabla$}

The authors thank Colciencias and the University of Cartagena for financial support of this research (grant 110751929179-2010). Professor Lia Barrios is also acknowledged for her collaboration with the histopathology analysis. Yanet Ocampo is deeply grateful to Colciencias and the University of Cartagena for her PhD fellowship through the National Program for Doctoral Formation (grant 597-2012) and the scholarship for excellent students (resolution 1446-2011), respectively.

\section{Conflict of Interest}

$\nabla$

The authors declare no conflicts of interest.

\section{References}

1 Sobolewski C, Legrand N, Morceau F, Diederich M. Inflammation: novel arrows for an ancient target. Biochem Pharmacol 2010; 80: 1769-1770

2 Wittmann C, Chockley P, Singh S, Pase L, Lieschke GJ, Grabher C. Hydrogen peroxide in inflammation: messenger, guide, and assassin. Adv Hematol 2012; 2012: 541471

3 Al-Reza SM, Yoon JI, Kim HJ, Kim JS, Kang SC. Anti-inflammatory activity of seed essential oil from Zizyphus jujuba. Food Chem Toxicol 2010; 48: 639-643

4 Burk DR, Senechal-Willis P, Lopez LC, Hogue BG, Daskalova SM. Suppression of lipopolysaccharide-induced inflammatory responses in RAW
264.7 murine macrophages by aqueous extract of Clinopodium vulgare L. (Lamiaceae). J Ethnopharmacol 2009; 126: 397-405

5 Morley J. Inflammation and asthma therapy: a false dawn. Pulm Pharmacol Ther 2006; 19: 200

6 Vidal-Vanaclocha F. Inflammation in the molecular pathogenesis of cancer and atherosclerosis. Reumatol Clin 2009; 5: 40-43

7 Mustafa A, El-Medany A, Hagar HH, El-Medany G. Ginkgo biloba attenuates mucosal damage in a rat model of ulcerative colitis. Pharmacol Res 2006; 53: 324-330

8 Llorca J, Lopez-Diaz MJ, Gonzalez-Juanatey C, Ollier WER, Martin J, Gonzalez-Gay MA. Persistent chronic inflammation contributes to the development of cancer in patients with rheumatoid arthritis from a defined population of northwestern Spain. Semin Arthritis Rheum 2007; 37: 31-38

9 Heo SJ, Yoon WJ, Kim KN, Ahn GN, Kang SM, Kang DH, Affan A, Oh C, Jung $W K$, Jeon YJ. Evaluation of anti-inflammatory effect of fucoxanthin isolated from brown algae in lipopolysaccharide-stimulated RAW 264.7 macrophages. Food Chem Toxicol 2010; 48: 2045-2051

$10 \mathrm{Wu}$ SJ, Ng LT, Chen CH, Lin DL, Wang SS, Lin CC. Antihepatoma activity of Physalis angulata and P. peruviana extracts and their effects on apoptosis in human Hep G2 cells. Life Sci 2004; 74: 2061-2073

11 Chang J, Lin C, Wu S, Lin D, Wang S, Miaw C, Ng L. Antioxidative and hepatoprotective effects of Physalis peruviana extract against acetaminophen-induced liver injury in rats. Pharm Biol 2008; 46: 724-731

12 Wu SJ, Ng LT, Huang YM, Lin DL, Wang SS, Huang SN, Lin CC. Antioxidant activities of Physalis peruviana. Biol Pharm Bull 2005; 28: 963-966

13 Wu SJ, Ng LT, Lin DL, Huang SN, Wang SS, Lin CC. Physalis peruviana extract induces apoptosis in human Hep G2 cells through CD95/CD95 L system and the mitochondrial signaling transduction pathway. Cancer Lett 2004; 215: 199-208

14 Yen CY, Chiu CC, Chang FR, Chen JYF, Hwang CC, Hseu YC, Yang HL, Lee AYL, Tsai MT, Guo ZL. 43-Hydroxywithanolide E from Physalis peruviana (golden berry) inhibits growth of human lung cancer cells through DNA damage, apoptosis and G2/M arrest. BMC Cancer 2010; 10: 46

15 Wu SJ, Chang SP, Lin DL, Wang SS, Hou FF, Ng LT. Supercritical carbon dioxide extract of Physalis peruviana induced cell cycle arrest and apoptosis in human lung cancer H661 cells. Food Chem Toxicol 2009; 47: $1132-1138$

16 Lan YH, Chang FR, Pan MJ, Wu CC, Wu SJ, Chen SL, Wang SS, Wu MJ, Wu YC. New cytotoxic withanolides from Physalis peruviana. Food Chem 2009; 116: 462-469

17 Arun M, Asha V. Preliminary studies on antihepatotoxic effect of Physalis peruviana Linn. (Solanaceae) against carbon tetrachloride induced acute liver injury in rats. J Ethnopharmacol 2007; 111: 110-114

18 Mora AC, Aragón DM, Ospina LF. Effects of Physalis peruviana fruit extract on stress oxidative parameters in streptozotocin-diabetic rats. Lat Am J Pharm 2010; 29: 1132-1136

19 Martinez W, Ospina LF, Granados D, Delgado G. In vitro studies on the relationship between the anti-inflammatory activity of Physalis peruviana extracts and the phagocytic process. Immunopharmacol Immunotoxicol 2010; 32: 63-73

20 Franco LA, Matiz GE, Calle J, Pinzón R, Ospina LF. Anti-inflammatory activity of extracts and fractions obtained from Physalis peruviana L. calyces. Biomedica 2007; 27: 110-115

21 Wu S, Tsai J, Chang S, Lin D, Wang S, Huang S, Ng L. Supercritical carbon dioxide extract exhibits enhanced antioxidant and anti-inflammatory activities of Physalis peruviana. J Ethnopharmacol 2006; 108: 407-413

22 Trinchero GD, Sozzi GO, Cerri AM, Vilella F, Fraschina AA. Ripening-related changes in ethylene production, respiration rate and cell-wall enzyme activity in goldenberry (Physalis peruviana L.), a solanaceous species. Postharvest Biol Technol 1999; 16: 139-145

23 Puente LA, Pinto-Muñoz CA, Castro ES, Cortés M. Physalis peruviana Linnaeus, the multiple properties of a highly functional fruit: a review. Food Res Int 2011; 44: 1733-1740

24 Valdenegro M, Fuentes L, Herrera R, Moya-León MA. Changes in antioxidant capacity during development and ripening of goldenberry (Physalis peruviana $\mathrm{L}$.) fruit and in response to 1-methylcyclopropene treatment. Postharvest Biol Technol 2012; 67: 110-117

25 Mazorra MF, Quintana ÁP, Miranda D, Fischer G, De Valencia MC. Anatomic aspects of formation and growth of the Cape gooseberry fruit Physalis peruviana (Solanaceae). Acta Biológica Colombiana 2006; 11: 69-81

26 Mayorga H, Duque C, Knapp H, Winterhalter P. Hydroxyester disaccharides from fruits of Cape gooseberry (Physalis peruviana). Phytochemistry 2002; 59: 439-445 
27 Ovenden SPB, Yu J, Bernays J, Wan SS, Christophidis LJ, Sberna G, Tait RM, Wildman HG, Lebeller D, Lowther J, Walsh NG, Meurer-Grimes BM. Physaloside A, an acylated sucrose ester from Physalis viscosa. J Nat Prod 2005; 68: 282-284

28 Pérez-Castorena AL, Luna M, Martínez M, Maldonado E. New sucrose esters from the fruits of Physalis solanaceus. Carbohydr Res 2012; 352: 211-214

29 Maldonado E, Torres FR, Martínez M, Pérez-Castorena AL. Sucrose esters from the fruits of Physalis nicandroides var. attenuata. J Nat Prod 2006; 69: 1511-1513

30 Gruda I, Milette D, Brother M, Kobayashi G, Medoff G, Brajtburg J. Structure-activity study of inhibition of amphotericin $B$ (Fungizone) binding to sterols, toxicity to cells, and lethality to mice by esters of sucrose. Antimicrob Agents Chemother 1991; 35: 24-28

31 Buapool D, Mongkol N, Chantimal J, Roytrakul S, Srisook E, Srisook K. Molecular mechanism of anti-inflammatory activity of Pluchea indica leaves in macrophages RAW 264.7 and its action in animal models of inflammation. J Ethnopharmacol 2013; 146: 495-504

32 Pérez-Castorena A, Martínez M, Maldonado E. Labdanes and sucrose esters from Physalis sordida. J Nat Prod 2010; 73: 1271-1276

33 Ferreira LC, Grabe-Guimarães A, de Paula CA, Michel MCP, Guimarães RG, Rezende SA, de Souza Filho JD, Saúde-Guimarães DA. Anti-inflammatory and antinociceptive activities of Campomanesia adamantium. J Ethnopharmacol 2013; 145: 100-108

34 Zanoni I, Ostuni R, Barresi S, Di Gioia M, Broggi A, Costa B, Marzi R, Granucci F. CD14 and NFAT mediate lipopolysaccharide-induced skin edema formation in mice. J Clin Invest 2012; 122: 1747-1757

35 Vinegar R, Schreiber W, Hugo R. Biphasic development of carrageenan oedema in rats. J Pharmacol Exp Ther 1969; 166: 96-103

36 Moita E, Gil-Izquierdo A, Sousa C, Ferreres F, Silva L, Valentão P, Domínguez-Perles R, Baenas N, Andrade P. Integrated analysis of COX-2 and iNOS derived inflammatory mediators in LPS-stimulated RAW macrophages pre-exposed to Echium plantagineum L. bee pollen extract. PLoS One 2013; 8: e59131
37 Kalinski P. Regulation of immune responses by prostaglandin E2. J Immunol 2012; 188: 21-28

38 Wang N, Yao X, Ishii R, Kitanaka S. Bioactive sucrose esters from Bidens parviflora. Phytochemistry 2003; 62: 741-746

39 Niu X, Xing W, Li W, Fan T, Hu H, Li Y. Isofraxidin exhibited anti-inflammatory effects in vivo and inhibited TNF- $\alpha$ production in LPS-induced mouse peritoneal macrophages in vitro via the MAPK pathway. Int Immunopharmacol 2012; 14: 164-171

40 Medeiros A, Peres-Buzalaf C, Fortino F, Serezani C. Prostaglandin E and the suppression of phagocyte innate immune responses in different organs. Mediators Inflamm 2012; 2012: 13

41 Mollace V, Muscoli C, Masini E, Cuzzocrea S, Salvemini D. Modulation of prostaglandin biosynthesis by nitric oxide and nitric oxide donors. Pharmacol Rev 2005; 57: 217-252

42 Salvemini D, Manning PT, Zweifel BS, Seibert K, Connor J, Currie MG, Needleman P, Masferrer JL. Dual inhibition of nitric oxide and prostaglandin production contributes to the antiinflammatory properties of nitric oxide synthase inhibitors. J Clin Invest 1995; 96: 301-308

43 Godin P. A new spray reagent for paper chromatography of polyols and cetoses. Nature 1954; 174: 134

44 Miller LC, Tainter ML. Estimation of the $\mathrm{ED}_{50}$ and its error by means of logarithmic-probit graph paper. Exp Biol Med 1944; 57: 261-264

45 Winter CA, Risley EA, Nuss GW. Carrageenin-induced edema in hind paw of the rat as an assay for antiiflammatory drugs. Proc Soc Exp Biol Med 1962; 111: 544-547

46 Mosmann T. Rapid colorimetric assay for cellular growth and survival: application to proliferation and cytotoxicity assays. J Immunol Methods 1983; 65: 55-63

47 Ferrari M, Fornasiero MC, Isetta AM. MTT colorimetric assay for testing macrophage cytotoxic activity in vitro. J Immunol Methods 1990; 131: $165-172$

48 Green LC, Wagner DA, Glogowski J, Skipper PL, Wishnok JS, Tannenbaum $S R$. Analysis of nitrate, nitrite, and [15N]nitrate in biological fluids. Anal Biochem 1982; 126: 131-138 